\title{
Pemodelan dan Analisa Antilock Braking System (ABS) Pada Military Vehicle Studi Kasus Panser Anoa APC 6X6
}

\author{
Muhammad Jundulloh dan I Nyoman Sutantra \\ Teknik Mesin, Fakultas Teknologi Industri, Laboratorium Otomotif, Institut Teknologi Sepuluh \\ Nopember (ITS) \\ e-mail: tantra@me.its.ac.id
}

\begin{abstract}
Abstrak-Dari awal terciptanya hingga saat ini, berbagai macam sistem dalam kendaraan terus menjadi obyek penelitian misalnya keamanan, kenyamanan dan kemudahan dalam pemakaian serta keindahan desain interior dan eksterior dari bentuk kendaraan itu sendiri. Salah satu sistem yang sangat berperan penting dalam kendaraan adalah sistem pengereman yang mempunyai fungsi memberhentikan laju kendaraan. Salah satu metode untuk mengetahui performa dari sistem pengereman yaitu dengan melakukan pemodelan dinamis. Dalam studi ini akan dilakukan pemodelan Antilock Braking System dan analisa pada kendaraan Military Vehicle Panser Anoa APC 6X6. ABS diberikan di dua roda belakang dan parameter sistem rem sebelumnya diambil dari PT PINDAD. Lalu hasil analisa ini didapat nilai gaya di brake pedal, gaya di booster rem, tekanan di master silinder, gaya di caliper, gaya dan torsi di disk pad. Setelah itu menambahkan komponen ABS kemudian dilakukan pemodelan dan simulasi dengan software dengan kecepatan Panser $60 \mathrm{~km} / \mathrm{jam}$ dan membandingkan stopping distance LBS terhadap ABS sesuai standar internasional serta perilaku beloknya. Skema untuk ABS Panser sama seperti yang LBS namun ada tambahan komponen seperti ABS Control Unit, Hydraulic Modulator dan Wheel Speed Sensor. Dan dari simulasi didapatkan respon stopping distance ABS = 16 meter, $\mathrm{LBS}=\mathbf{1 8 . 4 5}$ meter. Untuk waktu pengereman ABS $=1.94$ detik, $\mathrm{LBS}=\mathbf{2 . 2 0}$ detik. Nilai koefisien gesek lateral LBS $=0.00$ sedangkan untuk ABS nilai koefisien gesek lateralnya $=0.10-0.40$, sehingga perilaku belok LBS lebih cenderung oversteer dibanding ABS.
\end{abstract}

Kata Kunci-Antilock Braking System, ABS, Military Vehicle Dynamic, Stopping Distance.

\section{PENDAHULUAN}

$\mathrm{S}$ ISTEM pengereman dalam kasus ini conventional brake adalah sebuah sistem yang memiliki komponen seperti tuas rem, rem booster, master silinder, reservoir minyak rem, pipa rem, selang rem, kaliper, dan cakram. Antilock Braking System (ABS) sendiri mempunyai komponen yang sama dengan conventional brake, namun ada tambahan seperti $A B S$ control unit, kabel interkoneksi, modulator hidrolik (termasuk di dalamnya katup solenoid dan pompa), warning lamp $A B S$, sensor kecepatan roda. ABS pada dasarnya yaitu mendeteksi jika salah satu roda mengunci ketika proses pengereman dan ABS memastikan bahwa tekanan rem tetap konstan atau berkurang [1]. Dengan demikian dapat mencegah roda terkunci dan tetap steerable, dimana kendaraan bisa mengerem atau berhenti dengan cepat maupun aman.

Pada studi ini dilakukan pemodelan sistem pengereman Antilock Braking System dan menganalisa perilaku Panser Anoa APC 6X6. Dimana metode pendesainan adalah dengan melakukan redesign engineering sistem pengereman Panser yang telah ada dan menganalisa perilaku dengan simulasi pada software. Panser Anoa APC 6X6 ini akan menggunakan Antilock Braking System pada kedua roda belakangnya. Hal ini terkait pemikiran penulis beserta dosen pembimbing bahwa oversteer lebih berbahaya dibanding understeer dan faktor lainnya adalah keekonomisan. Parameter yang akan ditinjau adalah perilaku berbelok dan jarak pengereman ketika berjalan lurus.

\section{URAIAN PENELITIAN}

\section{A. Perhitungan center of gravity dan berat Panser dengan} penumpang

Untuk menentukan posisi center of gravity dari kendaraan, dapat dilakukan dengan cara menimbang bagian Panser dalam posisi datar maupun miring. PT. PINDAD sudah menimbang berat Panser sesuai regulasi dan didapat center of gravity seperti gambar 1 (kondisi tanpa penumpang).

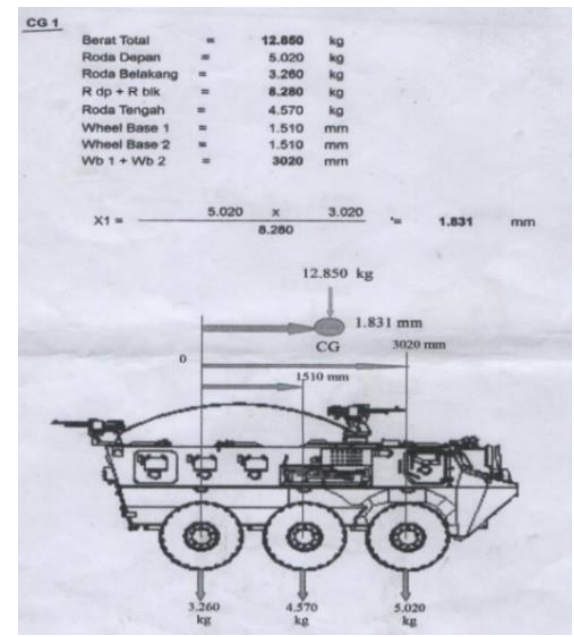

Gambar 1. Jarak CG dari roda depan dan belakang [2]

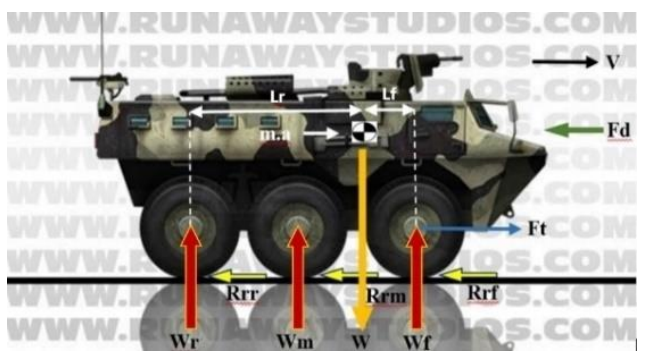

Gambar 2. Free body diagram Panser 


\section{B. Perhitungan Pada Komponen Rem \\ 1) Brake Pedal}

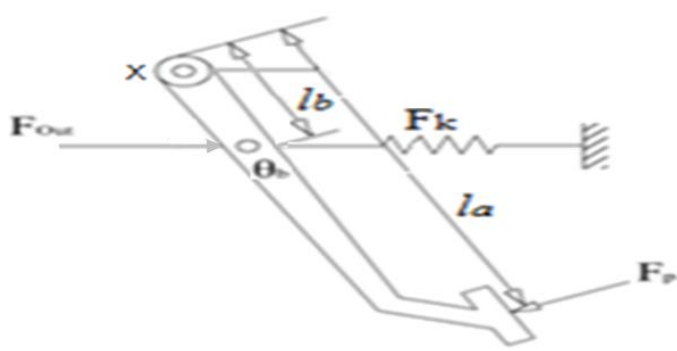

Gambar 3. Brake Pedal Schematic

Pedal merupakan masukan dari gaya pengereman, pada pembahasan ini gaya pedal yang diberikan adalah gaya maksimum dari injakan kaki pengemudi rata-rata gaya maksimum injakan kaki pengemudi adalah $30 \mathrm{~kg}$. Gaya yang dihasilkan dari pengereman akan di salurkan melalui push rod, sehingga dapat dihitung seperti dibawah ini :

$\sum_{F_{p} \cdot l_{a}}=\left(F_{\text {out }}+F k\right) \cdot l_{b} \cdot \sin \theta_{b}$

Gaya pegas

$\mathrm{F}_{\mathrm{k}}=\Delta \mathrm{x} \cdot \mathrm{k}$

dimana :

$\mathrm{F}_{\mathrm{k}}=$ gaya oleh pegas $(\mathrm{N})$

$\mathrm{k}=$ kekakuan pegas $(\mathrm{N} / \mathrm{m})$

$\Delta \mathrm{x}=$ perubahan panjang pegas akibat $\mathrm{F}_{\mathrm{k}}(\mathrm{m})$

Gaya push rod

$\mathrm{F}_{\text {out }}=\frac{\mathrm{F}_{\mathrm{p}} \cdot \mathrm{l}_{\mathrm{a}}}{\mathrm{l}_{\mathrm{b}} \cdot \sin \theta_{\mathrm{b}}}-\mathrm{F}_{\mathrm{k}}$

$\mathrm{l}_{\mathrm{a}} \quad=$ jarak pedal rem ke tumpuan $(\mathrm{m})$

$\mathrm{l}_{\mathrm{b}} \quad=$ jarak push rod ke tumpuan $(\mathrm{m})$

$\mathrm{F}_{\mathrm{p}} \quad$ = gaya pedal oleh pengemudi $(\mathrm{N})$

$\mathrm{F}_{\text {out }}=$ gaya $\operatorname{push} \operatorname{rod}(\mathrm{N})$

\section{2) Brake Booster}

Gaya yang keluar dari push rod akan disalurkan melalui booster, pada saat melewati booster akan mengalami pembesaran gaya, hasil perhitungan gaya yang dikeluarkan dari booster adalah sebagai berikut :

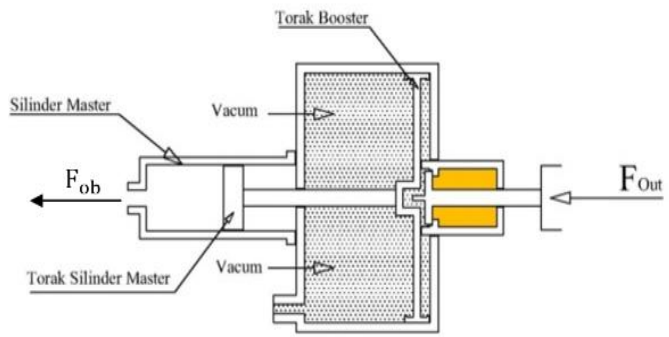

Gambar 4. Brake Booster Schematic

$\frac{F_{\text {ob }}}{F_{\text {out }}}=\frac{P_{\text {atm }}}{P_{\text {vcm }}}$

Gaya dari booster rem

$\mathrm{F}_{\mathrm{ob}}=\mathrm{F}_{\text {out }} \times \frac{\mathrm{P}_{\mathrm{atm}}}{\mathrm{P}_{\mathrm{vcm}}}$

$\mathrm{P}_{\mathrm{atm}}=$ tekanan $\operatorname{atmosfer}(\mathrm{Pa})$

$\mathrm{P}_{\mathrm{vcm}}=$ tekanan vakum (atm)

$\mathrm{F}_{\mathrm{ob}} \quad=$ gaya output booster rem $(\mathrm{N})$

\section{3) Master Silinder}

Gaya yang dikeluarkan dari booster akan diteruskan melalui master silinder, dibawah ini adalah perhitungan gaya yang dari keluar master silinder.

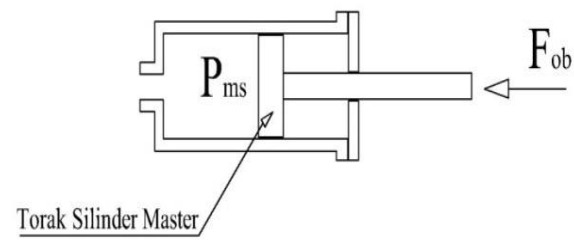

Gambar 5. Master Cylinder Schematic

Tekanan master silinder

$\mathrm{P}_{\mathrm{ms}}=\frac{\mathrm{F}_{\mathrm{ob}}}{0,25 \cdot \pi \cdot \mathrm{d}_{\mathrm{ms}}^{2}}$

$\mathrm{d}_{\mathrm{ms}}=$ diameter dalam master silinder $(\mathrm{m})$

$\mathrm{P}_{\mathrm{ms}}=$ tekanan master silinder $(\mathrm{Pa})$

\section{4) Kaliper}

Kaliper merupakan sebuah piston yang akan bergerak jika mendapatkan tekanan dari fluida, kaliper inilah yang nantinya akan mendorong pad dan akan bergesekan dengan disk brake.

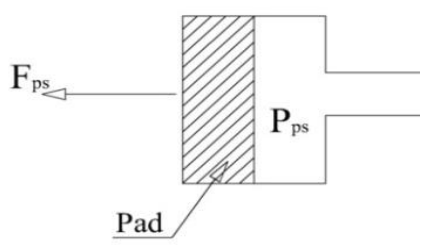

Gambar 6. Caliper Schematic

\section{$\underline{\text { Tekanan Kaliper }}$}

$\mathrm{P}_{\mathrm{ms}}=\mathrm{P}_{\mathrm{ps}}$

$\frac{F_{m s}}{A_{m s}}=\frac{F_{p s}}{A_{p s}}$

$A_{\mathrm{ps}}=$ luas pad caliper $\left(\mathrm{m}^{2}\right)$

$\mathrm{A}_{\mathrm{ms}}=$ luas master silinder $\left(\mathrm{m}^{2}\right)$

$\mathrm{F}_{\mathrm{ms}}=$ gaya master silinder $(\mathrm{N})$

Gaya Pad Silinder

$\mathrm{F}_{\mathrm{ps}}=\mathrm{A}_{\mathrm{ps}} \times \frac{\mathrm{F}_{\mathrm{ms}}}{\mathrm{A}_{\mathrm{ms}}}$

$\mathrm{F}_{\mathrm{ps}}=$ gaya pad silinder $(\mathrm{N})$

\section{5) Disc Brake}

Disk brake merupakan komponen yang terpasang pada roda berfungsi untuk menerima gaya yang dihasilkan dari master caliper yang akan diteruskan pada disk brake dan akan menghasilkan pengereman.

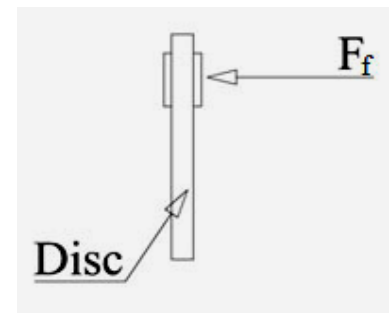

Gambar 7. Disc Brake Schematic 
Gaya gesek pad pada disk

$\mu_{\mathrm{d}}$ : koefisien disk pad - rigid molded asbestos

$\mathrm{F}_{\mathrm{f}}=\mathrm{F}_{\mathrm{ps}} \times \mu_{\mathrm{d}}$

$\mathrm{F}_{\mathrm{ps}}=$ Gaya pad silinder $(\mathrm{N})$

$\mathrm{F}_{\mathrm{f}}=$ Gaya gesek pad disk $(\mathrm{N})$

Torsi disk

$\mathrm{T}_{\mathrm{d}}=\mathrm{F}_{\mathrm{f}} \times \mathrm{R}_{\mathrm{d}}$

$\mathrm{R}_{\mathrm{d}}=$ jari-jari dinamis roda $(\mathrm{m})$

$\mathrm{T}_{\mathrm{d}}=$ Torsi $\operatorname{disk}(\mathrm{Nm})$

Perhitungan diatas merupakan pemodelan dengan gaya pedal sebagai input, ini adalah komponen utama sebagai penghasil gaya pengereman disamping transmisi kendaraan. Dalam pemodelan ini, gaya input pedal digunakan sebagai gaya yang menghambat laju kendaraan yang akan dibagi menjadi output yaitu sebagai torsi pengereman akibat bergesekan dengan disk brake dan gaya pengereman dari master caliper.

\section{Desain Skema Antilock Braking System}

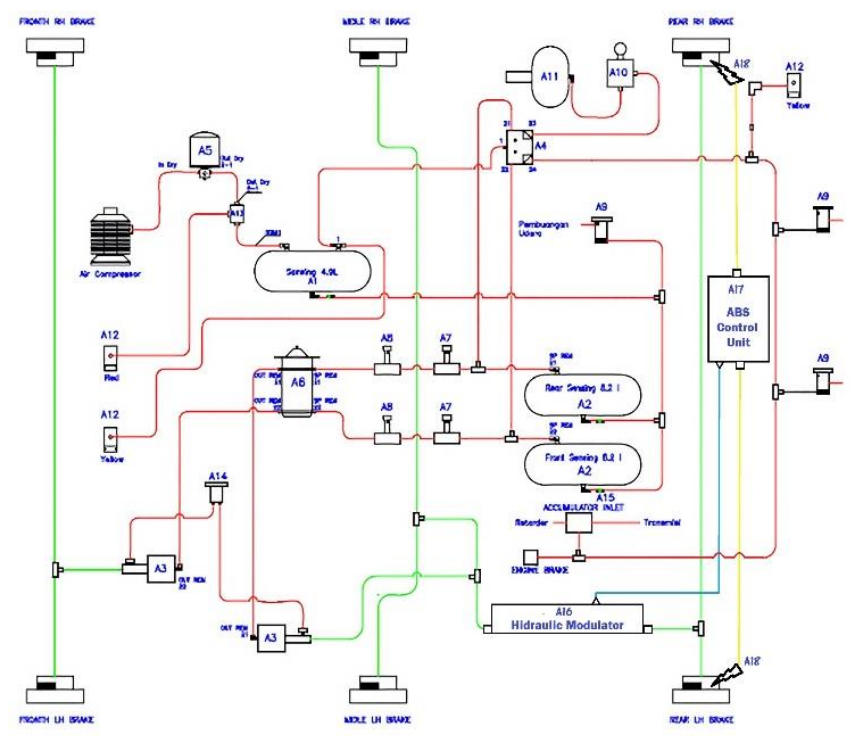

Gambar 8. Schematic Antilock Braking System

Keterangan :

A1 : Sensing

A2 : Roar Sensing

A3 : Master Cylinder

A4 : Protection Valve

A5 : Air Dryer

A6 : Foot Brake Valve

A7 : Air Pressure

A10 : Handle Hand Brake

A11 : Chamber

A12: Coupler

A13 : Double Check Valve

A14 : Oil T\&4

A15: Check Valve

A16 : Hydraulic Modulator

A8 : Air Press.Tranducer A17: ABS Control Unit

A9: Magnetic Valve A18: Wheel Speed Sensor

Pada gambar 8 terlihat komponen dari Antilock Braking System (ABS). Komponen ABS sendiri sama seperti gambar Lock Braking System (LBS), namun ada tambahan seperti $A B S$ control unit, hydraulic modulator, wheel speed sensor. Dimana ketiga komponen tersebut saling terintegrasi menjadi satu dengan komponen LBS.

Untuk skema LBS, alur gaya dan tekanan pengereman bisa sampai mengerem disk brake yaitu yang pertama ketika pedal rem terkena gaya oleh pengemudi. Lalu gaya tersebut melalui foot brake valve diteruskan ke booster rem dan secara otomatis gaya tersebut di boost. Setelah dari booster rem, input gaya tersebut masuk ke master silinder dan outputnya yaitu tekanan. Tekanan tersebut menekan fluida rem melalui house line brake, hingga sampai ke caliper. Input tekanan dari caliper dikonversi menjadi output gaya. Dan gaya tersebut ditransmisikan ke disk pad. Setelah sampai di disk, ada gaya rem dan torsi yang terjadi disana.

Untuk skema ABS sendiri sama alurnya dengan LBS, tetapi dari output master silinder yang berupa tekanan tersebut harus melewati modulator hidrolik dahulu, setelah itu baru dapat ke caliper. Setelah ke caliper maka akan diteruskan tekanan tersebut ke disk pad. Untuk ABS Panser sendiri, di dua roda belakangnya terdapat sensor kecepatan roda yang terintegrasi dengan $A B S$ control unit.

Khusus untuk fungsi komponen ABS utama yaitu $A B S$ control unit, hydraulic modulator, wheel speed sensor akan dibahas fungsinya secara garis besar disini. Sensor ini akan mendeteksi perubahan kecepatan, yang akan menjadi input signal dimana akan dikirimkan ke $A B S$ control unit selaku otak dari sistem antilock ini. Setelah sampai di $A B S$ control unit, sinyal tersebut diproses sangat cepat dan sinyal tersebut dikirimkan ke modulator hidrolik, dimana output dari modulator hidrolik adalah actuator yaitu pergerakan katup solenoid.

Dengan demikian terjadi perbedaan kinerja dari Antilock Braking System dibanding Lock Braking System. Karena LBS murni menggunakan mekanis semua, dibanding ABS yang sudah mengintegrasi mekanis dan elektrik. Terdapat kontrol pada sistem ABS, sedangkan LBS tidak. Analoginya LBS memakai open control loop system, sedangkan ABS memakai close control loop system karena terdapat feedback berupa fluktuatif putaran roda.

\section{Pemodelan Kendaraan}

\section{1) Pemodelan Dinamis Kendaraan}

Pemodelan dinamis kendaraan merupakan salah satu pemodelan matematis yang menganalisa gaya-gaya kendaraan pada saat pengereman, pada pemodelan ini ditekankan pada pengaruh slip yang terjadi pada saat roda lock, yang mempengaruhi roda lock yaitu tekanan pengereman yang lebih besar dari beban kendaran dikalikan koefisien gesek $(\mathrm{Fb}>\mu \mathrm{x} \mathrm{W})$.

Roda mengalami lock:

$F_{b}=\mu \times W$

Hukum Newton II

$\sum F=m \times a$

$\mathrm{F}_{\mathrm{b}}+\mathrm{R}_{\mathrm{r}}+\mathrm{R}_{\mathrm{a}}=\mathrm{m} \times \mathrm{a}$

$\mathrm{a}=\frac{\mathrm{F}_{\mathrm{b}}+\mathrm{R}_{\mathrm{r}}+\mathrm{R}_{\mathrm{a}}}{\mathrm{m}}$

Hambatan rolling dan hambatan aerodynamic

$\mathrm{R}_{\mathrm{r}}=\mathrm{F}_{\mathrm{r}} \times \mathrm{r}_{\text {dinamis }} \times \mu_{\mathrm{d}}$

$\mathrm{R}_{\mathrm{a}}=\frac{1}{2} \times \rho \times \mathrm{C}_{\mathrm{d}} \times \mathrm{A}_{\mathrm{f}} \times \mathrm{V}^{2}$

Radius dinamis roda

$r_{\text {dinamis }}=r_{W}+\frac{r_{W}-r_{\text {tire }}}{2}$

\section{2) Pemodelan Roda Kendaraan}

Pemodelan matematis ini meliputi torsi yang bekerja pada roda kendaraan dan berpengaruh pada saat terjadi pengereman, selanjutnya akan menjadi acuan untuk membuat 
pemodelan dengan menggunakan blok diagram simulasi dari program, berikut adalah free body diagram dari roda kendaraan.

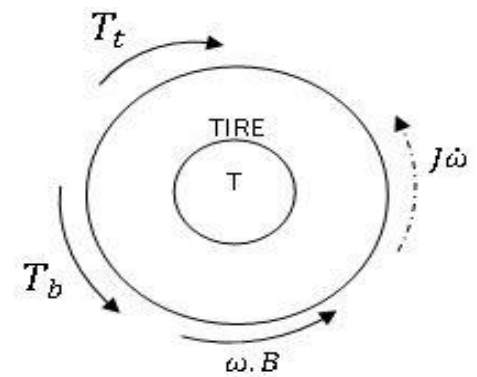

Gambar 9. Free body diagram brake dan roda

$\underline{\text { Inersia roda }}$

$\mathrm{J}=\frac{1}{2} \cdot \mathrm{m} \cdot\left(\mathrm{r}_{\text {tire }}{ }^{2}+\mathrm{r}_{\mathrm{w}}{ }^{2}\right)$

$\underline{\text { Torsi traktif }}$

$\mathrm{T}_{\mathrm{t}}=\mathrm{F}_{\mathrm{t}} \cdot \mathrm{r}_{\text {dinamis }}$

Torsi brake

$\mathrm{T}_{\mathrm{b}}=\mathrm{F}_{\mathrm{b}} \cdot \mathrm{r}_{\text {dinamis }}$

$\underline{\text { Redaman jalan (torsi gesek) }}$

$\omega_{\mathrm{W}} \cdot \mathrm{B}=\mathrm{W} \cdot \mathrm{r}_{\mathrm{w}} \cdot \mu_{\mathrm{d}}$

\section{E. Pemodelan di Simulink}

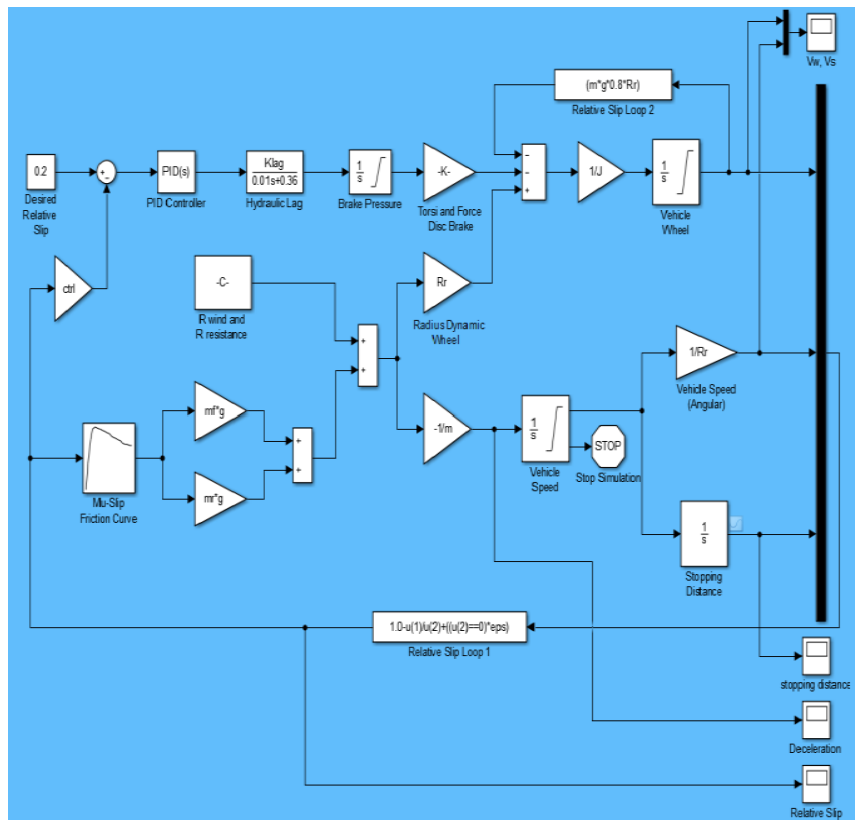

Gambar 10. Blok Simulink MATLAB Antilock Braking System

Setelah mendapatkan pemodelan matematis dari dinamika kendaran pada saat terjadi pengereman maka selanjutnya akan dibuat blok-blok diagram pada program MATLAB sesuai dengan pemodelan matematis diatas, berikut merupakan blok simulasi dari program MATLAB. Pada simulink ini ada beberapa parameter pemodelan yang di tuliskan pada $m$-script.

Tabel 1.

Data spesifikasi Panser Anoa APC 6X6[3]

\begin{tabular}{cc}
\multicolumn{2}{c}{ Dimensi Kendaraan } \\
Jarak sumbu roda & $3020 \mathrm{~mm}$ \\
Lebar & $2035 \mathrm{~mm}$ \\
Tinggi & $2170 \mathrm{~mm}$ \\
\hline
\end{tabular}

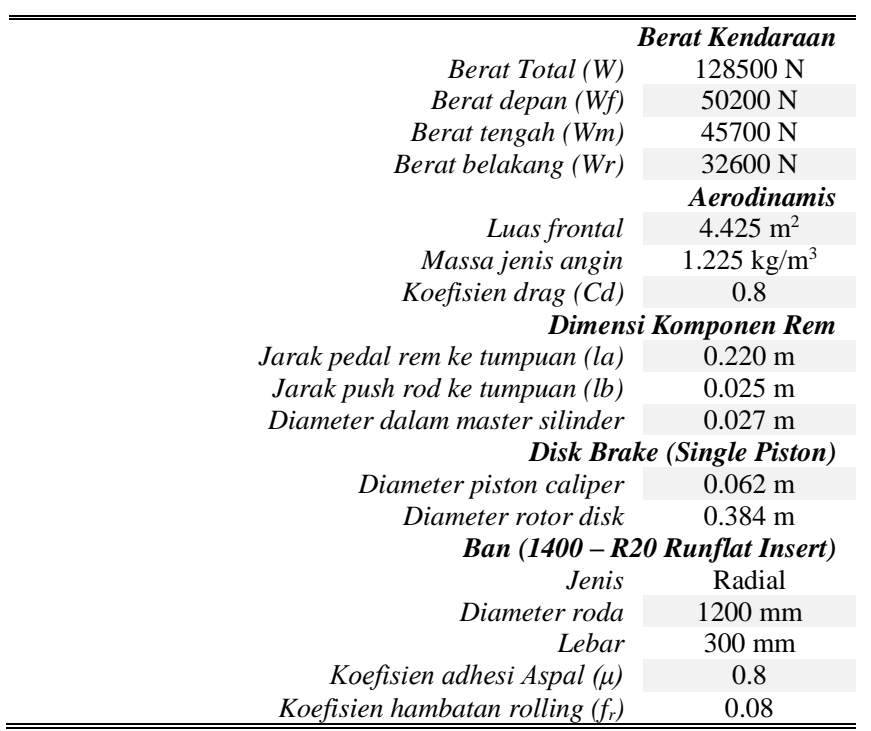

\section{HASIL DAN ANALISA}

Dari hasil pemodelan program MATLAB untuk sistem pengereman Lock Braking System (LBS) dan Antilock Braking System (ABS) di dapatkan beberapa karakteristik pengereman. Pada studi ini dilakukan simulasi untuk kecepatan $60 \mathrm{~km} / \mathrm{jam}$ pada jalan lurus. Hasil simulasi dari kecepatan $60 \mathrm{~km} / \mathrm{jam}$ akan ditampilkan sebagai berikut.

1) Respon Relative Slip

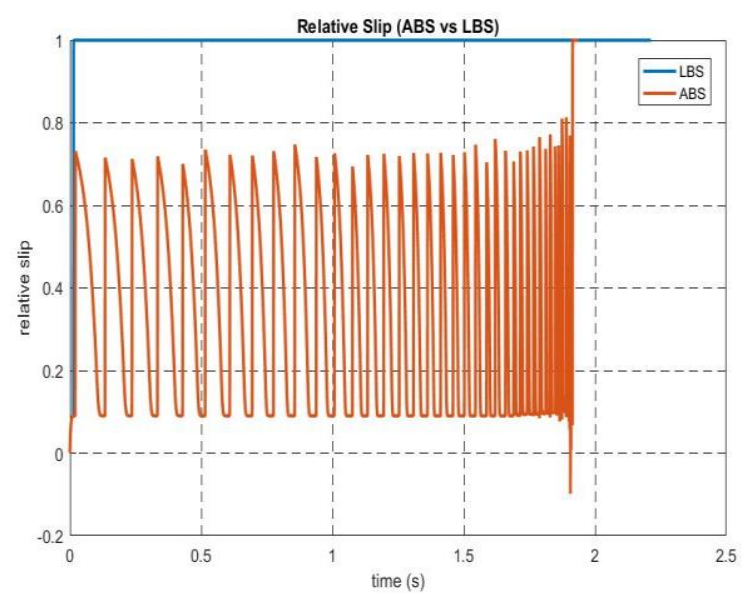

Gambar 11. Grafik perbandingan respon slip LBS dan ABS

Gambar diatas adalah grafik hasil dari simulasi perbandingan, antara respon slip roda lock braking dengan antilock braking system. Pada sistem antilock respon slip dijaga pada kondisi 10\% - 70\% hingga berhenti di 1.94 detik, sedangkan untuk sistem lock $100 \%$ respon slip terjadi saat 0.13 detik dan akan berhenti pada 2.20 detik. 


\section{2) Respon Stopping Distance}

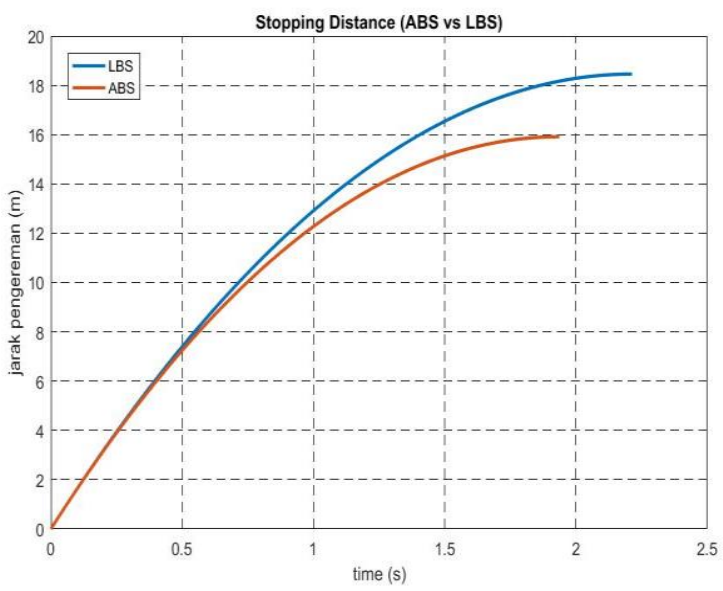

Gambar 12. Grafik perbandingan jarak pengereman LBS dan ABS

Gambar diatas merupakan grafik perbandingan dari hasil simulasi jarak pengereman dengan kecepatan kendaraan 60 $\mathrm{km} / \mathrm{jam}$ dari pengereman sistem antilock dengan sistem lock, pada sistem antilock yang ditandai warna merah, kendaraan akan berhenti pada 16 meter di 1.94 detik sedangkan pada sistem lock kendaran akan berhenti pada 18.45 meter di 2.20 detik, hal ini menunjukkan bahwa sistem pengereman antilock lebih dekat jarak pemberhentiannya dari pada sistem pengereman lock.

\section{3) Respon Kecepatan Angular Roda - Kecepatan Kendaraan}

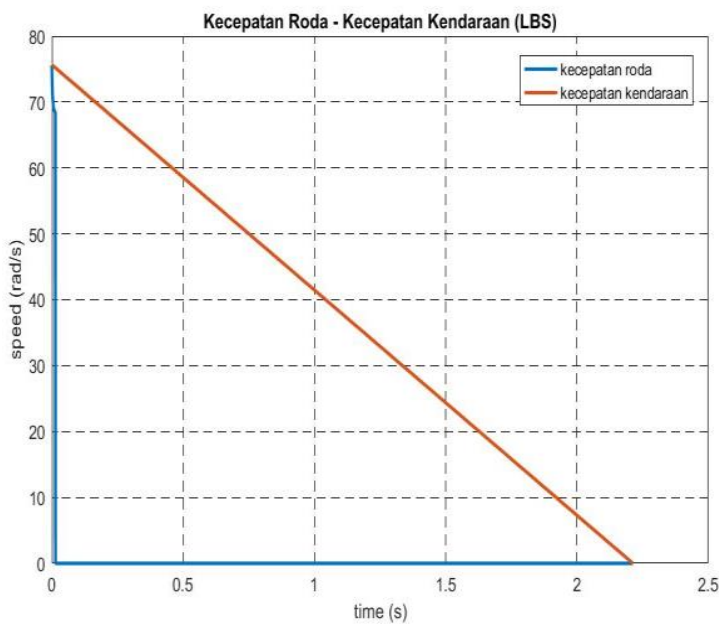

Gambar 13. Grafik kecepatan angular roda dan kendaraan LBS

Gambar diatas merupakan grafik kecepatan angular roda dan kendaraan pada lock braking hasil dari simulasi MATLAB, grafik diatas menunjukkan kecepatan angular roda ( $\mathrm{rad} / \mathrm{s})$ mencapai nilai 0.00 di 0.01 detik dan tidak menunjukkan fluktuasi kecepatan hingga berhenti akibat dari respon slip yang terjadi pada roda, maka bisa dikatakan slip kendaraan adalah $100 \%$.

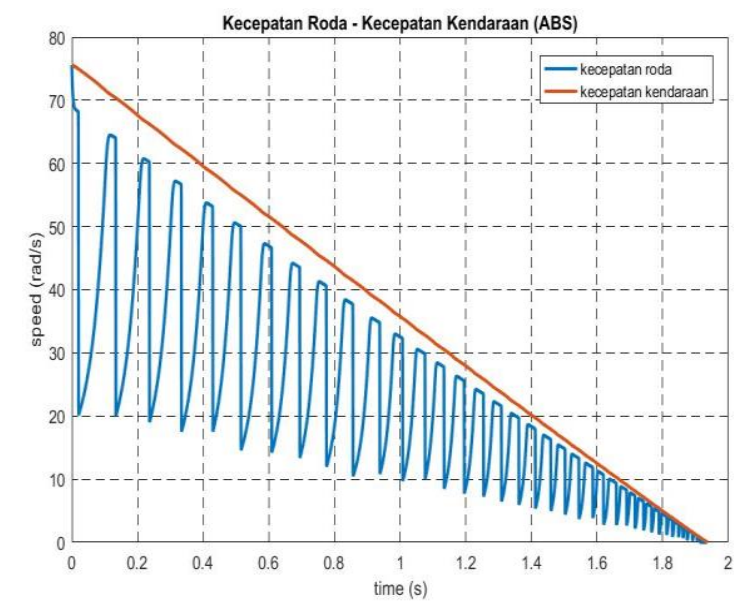

Gambar 14. Grafik kecepatan angular roda dan kendaraan ABS

Gambar diatas merupakan grafik kecepatan angular roda dan kendaraan pada antilock braking hasil dari simulasi MATLAB, pada kecepatan angular roda mengalami penurunan pertama dari $75.59 \mathrm{rad} / \mathrm{sec}$ menjadi $20.82 \mathrm{rad} / \mathrm{sec}$ dan seterusnya hingga berhenti pada 1.94 detik. Kecepatan awal kendaraan $16.67 \mathrm{~m} / \mathrm{s}$ dan berhenti pada 1.94 detik sama seperti kecepatan angular roda. Roda mengalami slip 0.05 detik, no slip 0.15 detik dan berfluktuasi terus hingga berhenti di 1.94 detik.

\section{4) Respon Perlambatan}

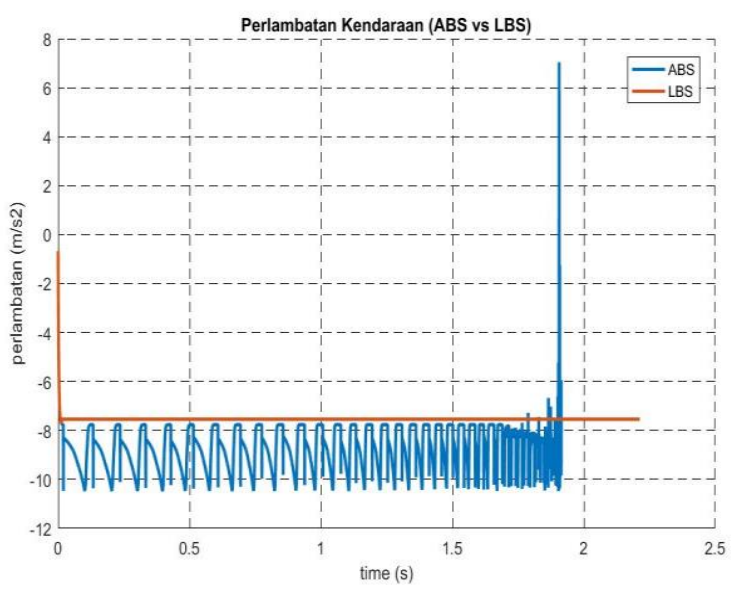

Gambar 15. Grafik perbandingan perlambatan kendaraan LBS dan ABS

Gambar diatas adalah grafik perbandingan perlambatan LBS dengan ABS pada sistem lock ditunjukkan warna merah perlambatan awal pada 0.0 .15 detik yaitu $8.50 \mathrm{~m} / \mathrm{s}^{2}$ kemudian pada 0.126 detik perlambatan menjadi $7.54 \mathrm{~m} / \mathrm{s}^{2}$ sedangkan pada antilock perlambatan yang terjadi 7.76 $\mathrm{m} / \mathrm{s}^{2}$ di 0.012 detik hingga $10.46 \mathrm{~m} / \mathrm{s}^{2}$ sampai kendaraan berhenti.

\section{5) Respon Perilaku Belok}

Respon perilaku belok kendaraan terlihat pada hubungan gambar 11 dan gambar 16. Gambar 16 menunjukkan pengaruh koefisien gesek longitudinal dan koefisien gesek lateral terhadap persentase lock roda. Besarnya angka koefisien gesek longitudinal mempengaruhi stopping distance sedangkan untuk koefisien gesek lateral mempengaruhi respon belok kendaraan saat mengerem. 


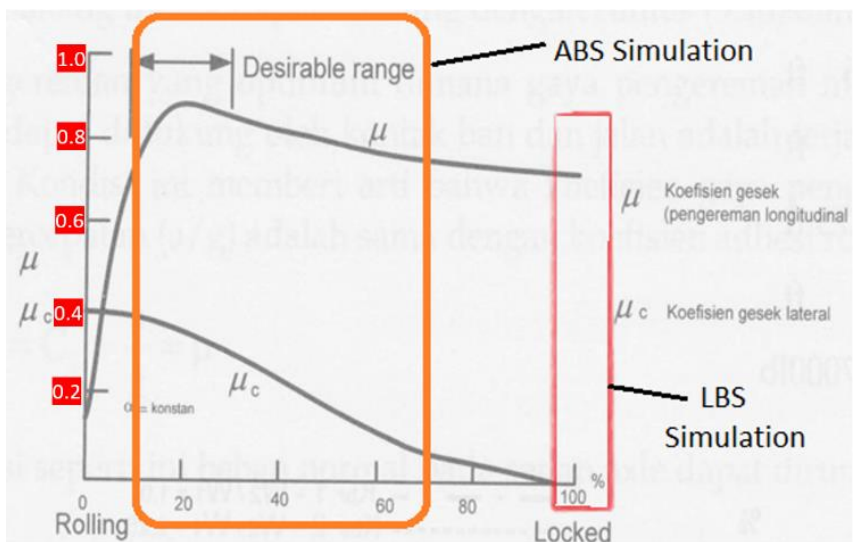

Gambar 16. Hubungan skid terhadap koefisien adhesi [3]

Lalu untuk gambar 11 menunjukkan relative slip - waktu Panser ABS dan LBS. Disini terlihat bahwa ABS mempunyai relative slip $=0.1-0.7$ yang berarti mempunyai kisaran nilai koefisien gesek longitudinal 0.75 - 0.90 dan lateral $0.10-$ 0.40 . Sedangkan untuk LBS mempunyai relative slip $=1$ (lock 100\%) yang berarti mempunyai kisaran nilai koefisien gesek longitudinal 0.75 dan lateral hampir 0.00. Salah satu parameter untuk melihat perilaku belok (kasus ini oversteer) yaitu besarnya nilai koefisien gesek lateralnya. Dan terlihat bahwa perbedaan koefisien gesek lateral ABS lebih besar dibanding LBS, oleh karena itu perilaku cenderung oversteer Panser lebih besar di sistem LBS dibanding sistem LBS. Kesimpulannya yaitu, stabilitas Panser saat berbelok lebih bagus pada Antilock Braking System dibanding dengan Lock Braking System.

Tabel 2.

Respon Parameter ABS dan LBS terhadap UK Standard Stopping Distance

\begin{tabular}{cccc}
\multicolumn{3}{c}{ Stopping Distance } \\
\hline \hline Parameter & ABS & LBS Standard & Stopping \\
$(60 \mathrm{~km} / \mathrm{h})$ & & Distance $^{[5]}$ \\
& & & \\
\end{tabular}

\begin{tabular}{cccc}
\hline Jarak pengereman $(\mathrm{m})$ & 16 & 18.45 & 22 \\
Waktu pengereman $($ det $)$ & 1.94 & 2.20 & - \\
Perlambatan $\left(\mathrm{m} / \mathrm{s}^{2}\right)$ & $7.76-$ & 7.54 & - \\
Relative slip & 10.49 & & - \\
\hline \hline
\end{tabular}

\section{KESIMPULAN}

Dari pemodelan, analisa data dan simulasi yang dilakukan maka didapatkan kesimpulan sebagai berikut :

- Respon jarak pengereman pada antilock braking system dan lock braking system yang ditunjukkan pada kecepatan $60 \mathrm{~km} / \mathrm{jam}$ yaitu untuk antilock braking system yaitu 16 meter, sedangkan untuk lock braking system adalah 18.45 meter. Disini dapat disimpulkan dari nilai jarak pengereman bahwa antilock braking system lebih baik daripada lock braking system.

- Respon waktu pengereman pada antilock braking system dan lock braking system yang ditunjukkan pada kecepatan $60 \mathrm{~km} / \mathrm{jam}$ untuk antilock braking system yaitu 1.94 detik. Sedangkan untuk lock braking system yaitu 2.20 detik. Terlihat sedikit perbedaan waktunya namun antilock braking system tetap lebih aman dibanding lock braking system.

- Karena hanya roda belakang yang ditambahkan komponen antilock braking, maka lock braking system lebih cenderung oversteer karena nilai koefisien gesek lateralnya hampir 0.00 sedangkan untuk antilock braking system nilai koefisien gesek lateralnya $0.10-0.40$.

\section{DAFTAR PUSTAKA}

[1]

K. Reif, "Brakes, Brake Control and Driver Assistance Systems," Springer Fachmedien Wiesbad., 2014.

P. PINDAD, Measurement Center of Gravity. 2016.

[3] B. Sutantra, I.N. dan Sampurno, Teknologi Otomotif. Surabaya: Guna Widya, 2010. 